\title{
Diminishing Chromium Use on Combined Chromium-Gambier Tanning Process Upon the Characteristics of Tanned Leather
}

\author{
A. Kasim*, D. Novia, S. Mutiar, \& A. Efendi \\ *Faculty of Agricultural Technology, Andalas University, Padang 25163, Indonesia \\ (Received 03-11-2013; Reviewed 21-01-2014; Accepted 08-04-2014)
}

\begin{abstract}
The research was aimed to investigate the influence of minimizing chromium use on combined chromium-gambier process upon the characteristics of tanned leather. At the first stage of tanning process, chromium was used and in the second stage it was replaced by gambier. The raw material used was dried saline-preserved goat skin. The treatments applied on the tanning process were the different concentrations of chromium ranging from the highest level of $6 \%$ to the lowest level of $1 \%$ which was then re-tanned by using $8 \%$ concentration of gambier. The examination parameters included chemical and physical properties as well as visual investigation on the tanned leather in accordance with SNI-06-0463-1989-A. The result showed that the tanning process by using $2 \%$ chromium in the first step and $8 \%$ gambier in the second step was a treatment combination producing tanned leather that met the standard. The examination on tanned leather resulted from such treatment showed $56.33 \%$ rawhide, $17.45 \%$ of bound tannin, $31.22 \%$ of tanning level, tensile strength $386.30 \mathrm{~kg} / \mathrm{cm}^{2}$, flexibility $31.91 \%$, leather width $1.3 \mathrm{~mm}$, density $0.75 \mathrm{~g} / \mathrm{cm}^{3}$, the leather was quite elastic with light brownish color. In conclusion, minimizing the use of chromium in the combined tanning process of chromium and gambier can be implemented to the lowest of $2 \%$ chromium concentration and $8 \%$ gambier in the first and second step, respectively.
\end{abstract}

Key words: gambier, leather, minimizing chromium, tanning

\begin{abstract}
ABSTRAK
Penelitian bertujuan untuk menguji pengaruh minimalisasi penggunaan kromium pada penyamakan kombinasi kromium-gambir pada karakteristik kulit tersamak. Penyamakan kulit tahap pertama dengan menggunakan kromium selanjutnya diikuti dengan penyamakan tahap kedua menggunakan gambir. Bahan baku yang digunakan dalam penelitian ini adalah kulit kambing kering awet garam. Perlakuan pada penyamakan adalah perbedaan konsentrasi kromium mulai dari konsentrasi tertinggi $6 \%$ sampai pada konsentrasi terendah $1 \%$, yaitu $6 \%, 5 \%, 4 \%, 3 \%, 2 \%$, dan $1 \%$, yang kemudian disamak ulang menggunakan gambir pada konsentrasi $8 \%$. Peubah yang diuji meliputi sifat kimia, sifat fisis, dan pengamatan visual kulit tersamak yang mengacu kepada SNI-06-0463-1989-A. Hasil penelitian menunjukkan bahwa penyamakan tahap pertama dengan menggunakan kromium $2 \%$ yang dilanjutkan dengan menyamakan tahap kedua menggunakan gambir pada konsentrasi $8 \%$ merupakan kombinasi perlakuan yang dapat menghasilkan kulit tersamak yang memenuhi standar. Hasil pengamatan terhadap kulit tersamak dari perlakuan tersebut adalah zat kulit mentah $56,33 \%$, kadar tanin terikat $17,45 \%$, derajat penyamakan $31,22 \%$, kekuatan tarik $386,30 \mathrm{~kg} / \mathrm{cm}^{2}$, kemuluran 31,91\%, tebal kulit 1,3 mm, densitas $0,75 \mathrm{~g} / \mathrm{cm}^{3}$, keadaan kulit cukup lemas, dan kulit berwarna light brownish. Dapat disimpulkan bahwa level kromium terendah pada proses penyamakan untuk menghasilkan kulit tersamak yang sesuai standar adalah sebesar $2 \%$ pada tahap pertama dan gambir sebesar $8 \%$ pada tahap kedua.
\end{abstract}

Kata kunci: gambir, kulit, penyamakan, minimalisasi kromium

*Corresponding author:

E-mail: anwar_ks@yahoo.com 


\section{INTRODUCTION}

Chromium was commonly used in industrial tanning leather since it is easy to proceed and the results of the tanned leather are more stable. According to Nasr et al. (2013); Haron et al. (2012); Darmawan (2012), chromium is one of the most common mineral tanning materials in the world and it is used by nearly $90 \%$ of tanneries. Chromium can alter the tanned leather to be more flexible, heat-proof and more elastic. However, it can pollute the environment and its toxic could be hazardous to living creatures. According to Ghani (2011); Jun et al. (2009), at a high concentration, the toxic could bring direct impact on physiological and biochemical functions of human body. The use of chromium as tanning agent is partly disposed along with the waste. According to Roig et al. (2012), chromium tannage involved serious environmental risks resulted from the possible oxidation of chromium to a hexavalent state, although tanners were aware of the carcinogenic effect, in accordance with the International Agency for Research on Cancer (IARC)

One of tannery industries in West Sumatra is UPTD of tanning leather of Padang Panjang. A combined tanning process of chromium and mimosa plant agents is used in this industry as much as $8 \%$ and $10 \%$, respectively. The use of $8 \%$ chromium is considerably high. BASF (2013) suggested that the tolerable amount of chromium use is only $2 \%$. Mimosa is an imported product, which can actually be replaced by other plants tanning agents. Faber et al. (1978) categorized gambier as a kind of special extract (tannin) used for tanning leather. According to Wina et al. (2010), tannin isolate could be used for several purposes such as tanning agent for leather. Data from National Statistics Bureau (BPS) revealed that in 2006 Indonesia exported 8000 tons of gambier to India. The abundance of gambier across the country can therefore be used as leather tanning agents to replace the mimosa. According to Kasim et al. (2013), the optimum concentration for using gambier as a tanning agent was $9 \%$.

Thus, a research on tanning leather process was conducted by minimizing the use of chromium concentration from the highest point of $6 \%$ to the lowest point of $1 \%$. The tanned leather was then re-tanned by using $8 \%$ of gambier concentration. The aim of the research was to find out the possibility of using as little chromium concentration as possible when it was combined with the gambier tanning agent. Aside from that, the research was aimed at investigating the possibility of gambier as the replacement tanning agent of mimosa.

\section{MATERIALS AND METHODS}

The materials used in this research included ten sheets dried goat skin of West Sumatera region, chromium oxide $\left(\mathrm{Cr}_{2} \mathrm{O}_{3}\right)$, gambier, limewater, sodium sulfide, sulfuric acid, sodium carbonate, sodium bicarbonate, formic acid, sodium hydroxide, ammonium sulphate, teepol, oropon, preventol, salt, hexane and red methyl indicator/methylene blue.
The research was conducted in two phases. First, chromium was used in a variety of concentration levels namely A: 0\%; B: 1\%; C:2\%; D:3\%; E:4\%; F:5\% and G: $6 \%$. The second phase applied gambier at $8 \%$ concentration.

\section{Research Implementation}

The following lists are tanning process procedure based on the methods which was modified from Office of Leather, Rubber and Plastic Tannery (Balai Besar Penyamakan Kulit, Karet dan Plastik) Yogyakarta (2011).

Pre-tanning process. The leather was soaked and put into a tanning drum. Some materials, 200\% water, 6\% limewater, and $4 \%$ sodium sulfide was mixed in the tanning drum for $2 \mathrm{~h}$. The percentage was based on the weight of fresh leather. The leather was washed to remove the remaining hair. Then, by using dull knife to peel off the fat and measure the bloten weight (weight of the leather after fat and hair removal). Leather was dipped into the tanning drum, then $100 \%$ water and $0.5 \%$ ammonium sulphate were poured and the drum was turned for 30 min with rotation of 8-10 rpm. After pouring $0.5 \%$ formic acid, the drum was turned again for another $30 \mathrm{~min}$. The percentage measurement was based on bloten weight. After deliming process from the leather and solution, 0.5 $\%$ teepol and $0.5 \%$ oropon were added and turned the drum for $30 \mathrm{~min}$. Afterwards, the leather was cleaned and put it into tanning drum, $80 \%$ water and $10 \%$ salt were poured and the drum was turned again for $30 \mathrm{~min}$. About $1.5 \%$ sulfate acid was solved with water by $1: 10$ ratio and the drum was turned for $30 \mathrm{~min}$. After $0.01 \%$ preventol addition, the drum was turned again for 10 min. The solution acidity was adjusted to $\mathrm{pH} 3$.

Tanning process by using chromium (the first step tanning). Tanning leather by using chromium at various concentrations (A: 1\%, B: $2 \%$, C: $3 \%$, D: $4 \%$, E: $5 \%$, and F: $6 \%$ ) which was measured based on the bloten weight was done in the drum and turned for $60 \mathrm{~min}$. About $0.5 \%$ of sodium formic was added and the tanning drum was turned for $30 \mathrm{~min}$. Then, $0.5 \%$ of sodium bicarbonate was added and the drum was turned again for $30 \mathrm{~min}$. After $24 \mathrm{~h}$, the leather was washed.

Re-tanning by using gambier (second step tanning). About $1 \%$ natrium bicarbonate was added into the tanned leather (of the first step) and the drum was turned for 30 min. The solution acidity was adjusted to $\mathrm{pH} 7$ and the leather was cleaned off.

On the second step tanning, the leather was dipped into the tanning drum and was added by $100 \%$ water and $8 \%$ gambier. The $\mathrm{pH}$ was adjusted to $\mathrm{pH} 4$ and the drum was turned for $60 \mathrm{~min}$. The leather was immersed for $24 \mathrm{~h}$ to clean off the remaining tanning agents and was stretched to dry it.

\section{Tanned Leather Examination}

The tanned leather examination included chemical and physical property use in tensile strength meter 
and visual examination of the tanned leather with the method of SNI-06-0463-1989-A. Regression analysis was used to observe the correlation of various levels of chromium concentration used and $8 \%$ concentration of gambier to the amount of bound tannin and tanning level in tanned leather.

\section{RESULTS AND DISCUSSION}

\section{Chemical Analysis on Tanned Leather}

Table 1 shows the amount of bound tannin, tanning level and content of rawhide. The amount of bound tannin was the remaining component found in the tanned leather after diminishing water, oil, water-solvent substances, dust, and rawhide substance.

The research showed that the amount of bound tannin ranged from $10.84 \%$ to $28.01 \%$. The declining trend of amount of bound tannin was in line with the lowering level of chromium concentration used in the first step tanning. The amount of bound tannin increases by $3.19 \%$ (from $10.84 \%$ without the first step tanning to $14.03 \%$ ) by using only $1 \%$ chromium in the first step and $8 \%$ gambier in the second step. The use of $5 \%$ chromium and $8 \%$ gambier in the first and second step correspondingly produced bound tannin with the highest level and the amount declines if $6 \%$ chromium was used in the first step. It showed that the initial tanning using chromium and re-tanned using gambier could increase the amount of bound tannin as well as improved the quality of tanned leather. According to Roig et al. (2012), the tanning process using chromium triggers as interaction between chromium and carbosilate cluster in skin collagen through a chemical bond, could make the leather stronger and more elastic.

Sahubawa et al. (2011) pointed out that the mixture of different tanning agents could restore and improve the quality of tanned leather since each tanning agent could fix each other. The chromium would react to form a bond with free amino acid which could be found in the structure of reactive collagen protein. In addition, Roig et al. (2012) explained that during a tanning process the chromium would form a cross bond that transformed the raw leather to be more resilient to either chemical or physical effect. Similarly, the gambier could easily be penetrated to the leather. According to Dhalimi (2006), Kardell et al. (2013), the gambier was ease raw material for sunlight proof color agent and for leather processing. It was categorized as a special extract for tanning leather, it was also dissolved quickly with the skin protein to create a soft and smooth tanned leather.

According to Wiyodiningrat et al. (2012), there were 2 kinds of formula, namely: combination tanning, chrome tanning agents $2 \%$ and $4 \%$, combined with synthetic tanning agents (16\% and $20 \%$ ), and combination tanning of vegetable tanning agents (15\% and $26 \%$ ) with synthetic tanning agents $(16 \%$ and $18 \%)$. The research showed that the best formula for making environmentally friendly upholstery leather was $4 \%$ chrome tanning, combined with syntan $4 \%$.

Tanning level of the tanned leather also indicated a similar trend with the amount of bound tannin. The tanning level tends to decline as the diminishing of chromium concentration used but higher concentration of chromium (6\%) showed lower point compared to $5 \%$ concentration. The tanning level in treatment A and B indicated a below standard result with tanning level of $15.92 \%$ and $24.11 \%$, respectively. The tanning level of tanned leather with treatment C, D, E, F, and G were met the standard. According to SNI-06-0463-1989-A, the minimum standard of tanning level was $25 \%$. The tanning level analysis aimed at investigating the amount of tanning agents which created a chemical bond in the collagen fiber tissue. The bond formation was determined by both chemical and physical structure of the leather as well as the tanning agents. The combined tanning process using gambier and chromium would form a cross-linking bond between leather collagen and tanning agents. Suparno et al. (2010) pointed out that combined tanning agents of chromium and plant-based agents could bring a synergic effect to form a stable bond.

Correlation of various levels of chromium concentration used and $8 \%$ concentration of gambier to the amount of bound tannin in tanned leather is shown in Figure 1. The amount of bound tanning was affected by characteristics of tanning agents penetrating to the leather. According to Roig et al. (2012), in the first step of tanning a reaction between hydroxyl cluster within

Table 1. Chemical analysis data of tanned leather using chromium at various level of concentration and gambier at the level of $8 \%$

\begin{tabular}{clrrc}
\hline & & \multicolumn{2}{c}{ Analysis of tanned leather (\%) } \\
\cline { 3 - 5 } Code & Treatment & $\begin{array}{c}\text { Amount of bound } \\
\text { tannin }\end{array}$ & Tanning level & $\begin{array}{c}\text { Content of raw } \\
\text { leather material }\end{array}$ \\
\hline G & 6\% chromium and 8\% gambier & $25.40 \pm 0.00$ & $54.83 \pm 0.74$ & $46.31 \pm 0.45$ \\
F & 5\% chromium and 8\% gambier & $28.01 \pm 0.00$ & $66.03 \pm 0.72$ & $43.72 \pm 0.00$ \\
E & 4\% chromium and 8\% gambier & $24.23 \pm 0.16$ & $50.71 \pm 0.77$ & $47.49 \pm 0.21$ \\
D & 3\% chromium and 8\% gambier & $19.44 \pm 0.00$ & $36.20 \pm 0.33$ & $53.67 \pm 0.29$ \\
C & 2\% chromium and 8\% gambier & $17.45 \pm 0.00$ & $31.22 \pm 0.00$ & $56.33 \pm 0.00$ \\
B & 1\% chromium and 8\% gambier & $14.03 \pm 0.28$ & $24.08 \pm 0.09$ & $58.26 \pm 0.00$ \\
A & 0\% chromium and 8\% gambier & $10.84 \pm 0.00$ & $21.97 \pm 0.13$ & $51.75 \pm 0.00$ \\
SNI-06-0463-1989-A & - & minimum 25\% & - \\
\hline
\end{tabular}


tanning agent and molecules of other tanning substances occured until the inter-skin fiber hollows were fully packed. Additionally, Suparno et al. (2010) stated that tanning process by using plant-based agent would form cross-linking bonds with the skin collagen, which were hydrogen and covalent bonds which made a stable tanned-leather. According to Ibrahim et al. (2005), the higher level of tanning agent concentration could form a faster bond reaction of plant-based tanning agent like gambier.

The tanning level indicated the level of leather ripeness. High tanning level shows perfect ripe leather with a good shape, but on the other hand if the tanning level is low, the leather will not be perfectly tanned. The correlation of the effect of chromium use with various levels of concentration and $8 \%$ concentration of gambier to the tanning level of tanned leather can be seen in Figure 2.

Figure 2 shows the tanning level in non-chromium $(0 \%)$ tanning process and tanning by using $1 \%$ chromium was below minimum standard of tanning leather level (25\%). Reducing the chromium concentration up to $2 \%$ in the first step which was followed by the second step tanning by using $8 \%$ concentration of gambier could produce a good quality leather that meet the standard. According to the Indonesia's National Standard (SNI 060994-1989-A), the tanning level determined the quality of the tanned leather. The higher the tanning level was, the

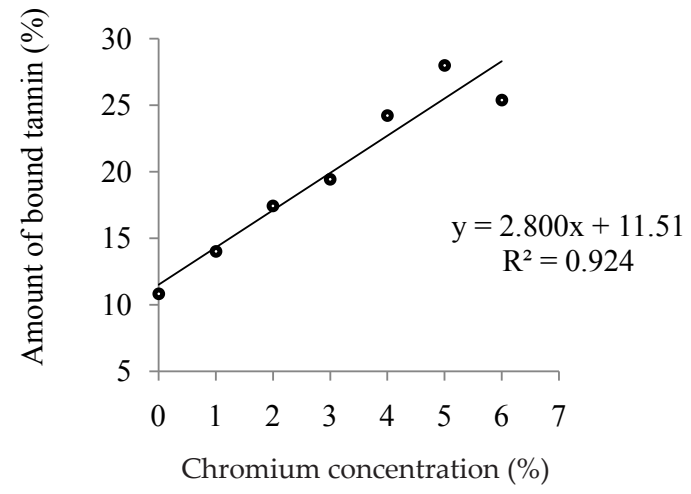

Figure 1. Correlation of chromium use with various level of concentration and $8 \%$ concentration of gambier with the amount of bound tannin in tanned leather better and stronger the leather would be. In contrast, the lower tanning level would produce low quality leather.

\section{Physical Characteristics of Tanned Leather}

Table 2 shows the measurement results of tensile strength of tanned leather by using chromium in the initial tanning process with various levels of concentration and $8 \%$ concentration of gambier. Leather physical characteristics can be defined as leather resistance to mechanical, humidity and temperature effect. The leather physical characteristics are determined by some factors such as collagen fiber, leather chemical composition and thickness of tanned leather.

The research showed the thickness of tanned leather varied from 0.8 to $2 \mathrm{~mm}$. The tanned leather would be thinner if the concentration of chromium in the first tanning was reduced and then re-tanned by using $8 \%$ concentration of gambier. The measurement result of the tanned leather thickness was supported with density rate, in which the tanned skin with higher density would produce thinner leather and skin with lower density would produce thick leather. Treatment B showed 0.8 $\mathrm{mm}$ thickness with density of $0.90 \mathrm{~g} / \mathrm{cm}^{3}$, whilst in treatment $\mathrm{G}$ the thickness of tanned leather was $2 \mathrm{~mm}$ with density of $0.56 \mathrm{~g} / \mathrm{cm}^{3}$. The treatment using $4 \%$ chromium concentration which was lessened to $1 \%$ could produce

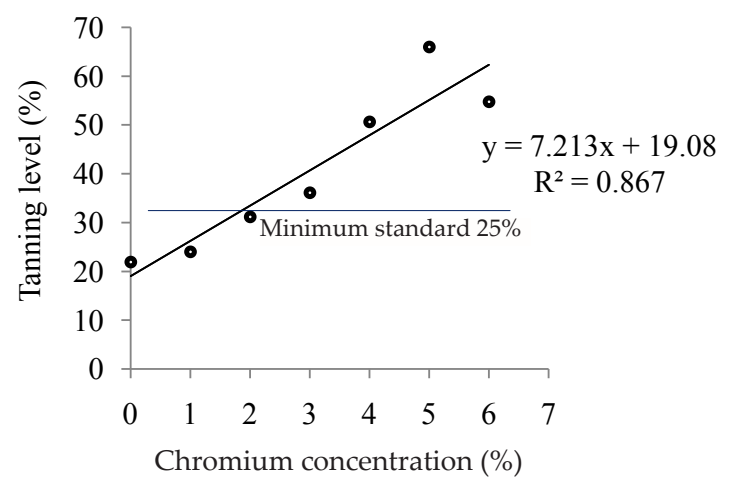

Figure 2. The correlation of chromium use with various levels of concentration and $8 \%$ concentration of gambier with the tanning level of tanned leather

Table 2. Physical analysis data of tanned leather using chromium at various levels of concentration and gambier at the level of $8 \%$

\begin{tabular}{clcccc}
\hline & & \multicolumn{3}{c}{ Tanned-leather physical characteristics } \\
\cline { 3 - 6 } Code & Treatment & $\begin{array}{c}\text { Thickness } \\
(\mathrm{mm})\end{array}$ & $\begin{array}{c}\text { Density } \\
\left(\mathrm{g} / \mathrm{cm}^{3}\right)\end{array}$ & $\begin{array}{c}\text { Tensile strength } \\
\left(\mathrm{kg} / \mathrm{cm}^{2}\right)\end{array}$ & $\begin{array}{c}\text { Elasticity } \\
(\%)\end{array}$ \\
\hline G & 6\% chromium and 8\% gambier & 2.0 & 0.56 & $176.27 \pm 23.94$ & 36.89 \\
F & 5\% chromium and 8\% gambier & 1.5 & 0.51 & $325.68 \pm 12.43$ & 46.04 \\
E & 4\% chromium and 8\% gambier & 0.8 & 0.80 & $356.76 \pm 1.14$ & 30.39 \\
D & 3\% chromium and 8\% gambier & 1.3 & 0.75 & $368.14 \pm 17.59$ & 45.59 \\
C & 2\% chromium and 8\% gambier & 1.3 & 0.67 & $386.30 \pm 19.74$ & 31.91 \\
B & 1\% chromium and 8\% gambier & 0.8 & 0.90 & $338.84 \pm 0.00$ & 21.14 \\
A & 0\% chromium and 8\% gambier & 1.1 & 0.64 & $403.40 \pm 0.00$ & 44.57 \\
SNI-06-0463-1989-A & $0.7-1.2 \mathrm{~mm}$ & - & min.75 $\mathrm{kg} / \mathrm{cm}^{2}$ & $*$ max.55\% \\
\hline
\end{tabular}


good quality tanned leather; meanwhile the use of $5 \%$ and $6 \%$ concentrations of chromium produced thick and poor quality leather. The leather thickness was influenced by the amount of tanning agents which was bound with skin collagen and tanning agents which filled up the empty space within the skin fiber, as shown by Table 1. According to Nasr et al. (2013), chromiumbased tanning leather would form a cross-linked bond between tanning agent and skin collagen. Diminishing the bond would lessen the leather's thickness and affect the water absorbance.

Tensile strength of tanned leather produced from each treatment met the standard. The highest tensile strength was found in the treatment A which was 403.40 $\mathrm{kg} / \mathrm{cm}^{2}$, whilst the lowest tensile strength was found in the treatment $\mathrm{G}$ using $6 \%$ chromium concentration and the re-tanned by using $8 \%$ concentration of gambier, namely $176.27 \mathrm{~kg} / \mathrm{cm}^{2}$. In addition, treatment $\mathrm{G}$ also contained relatively high bound tannin compared to the treatment B. Physical characteristics are affected by chemical composition of the tanned leather such as water content and bound tannin. According to Sahubawa et al. (2011), the water content within the tanned leather affected the ripeness level of skin collagen protein fiber, since the water which bonds to the leather would lessen the tensile and torn strength, and the bond between collagen fibers and tanning agents would determine the leather's tensile strength. This result was similar to Wiyodiningrat et al. (2012), stated that concentration of $2 \%$ chromium and leather combination with gambier $8 \%$ resulted high tensile strength, that was $386.30 \mathrm{~kg} / \mathrm{cm}^{2}$, compared with the combination of chromium and syntan tanning that was $211.81 \mathrm{~kg} / \mathrm{cm}^{2}$.

The physical characteristics of the tanned leather are one of the essential parameters in determining the quality of tanned leather, because it can portray the bond strength between skin-forming collagen and the applied tanning agents. The results of tensile strength measurement were affected by fiber tissues of skin collagen, physical structure, rawhide chemical substance and the tanning agents. The tensile strength of tanned leather of each treatment met the national standard SNI.06-09941989-A with minimal tensile strength $75 \mathrm{~kg} / \mathrm{cm}^{2}$.

\section{Examination of Tanned Leather Condition}

Visual examination results of the tanned leather using chromium in the initial step with various levels of concentration and $8 \%$ concentration of gambier are presented in Table 3. The leather's condition is the assessment result of elasticity level of the tanned leather product. Table 3 shows that the use of chromium in the first step tanning and then followed by the second tanning using gambier could produce elastic leather. The lower the chromium concentration used the lower the skin elasticity would be. Tanning leather using $4 \%$ chromium concentration and lower in the first step and using $8 \%$ concentration of gambier in the following step could produce fairly elastic leather. The higher the chromium concentration used the more elastic the leather would be. The tanned leather elasticity was affected by elastin protein which was found in the skin and tan-
Table 3. Examination data of tanned leather condition using chromium with various levels of concentration and gambier

\begin{tabular}{|c|c|c|c|}
\hline \multirow{2}{*}{ Code } & \multirow{2}{*}{ Treatment } & \multicolumn{2}{|c|}{$\begin{array}{l}\text { Examination of tanned } \\
\text { leather condition }\end{array}$} \\
\hline & & $\begin{array}{l}\text { Leather } \\
\text { condition }\end{array}$ & ${ }^{*}$ Color \\
\hline G & $\begin{array}{l}6 \% \text { chromium and } 8 \% \\
\text { gambier }\end{array}$ & Elastic & Light gray \\
\hline $\mathrm{F}$ & $\begin{array}{l}5 \% \text { chromium and } 8 \% \\
\text { gambier }\end{array}$ & Elastic & Olive yellow \\
\hline $\mathrm{E}$ & $\begin{array}{l}4 \% \text { chromium and } 8 \% \\
\text { gambier }\end{array}$ & Elastic & Light gray \\
\hline $\mathrm{D}$ & $\begin{array}{l}3 \% \text { chromium and } 8 \% \\
\text { gambier }\end{array}$ & $\begin{array}{l}\text { Less } \\
\text { elastic }\end{array}$ & Lihgt gray \\
\hline $\mathrm{C}$ & $\begin{array}{l}2 \% \text { chromium and } 8 \% \\
\text { gambier }\end{array}$ & $\begin{array}{l}\text { Less } \\
\text { elastic }\end{array}$ & $\begin{array}{c}\text { Light } \\
\text { brownish }\end{array}$ \\
\hline B & $\begin{array}{l}1 \% \text { chromium and } 8 \% \\
\text { gambier }\end{array}$ & $\begin{array}{l}\text { Less } \\
\text { elastic }\end{array}$ & Gray \\
\hline A & $\begin{array}{l}0 \% \text { chromium and } 8 \% \\
\text { gambier }\end{array}$ & $\begin{array}{l}\text { Less } \\
\text { elastic }\end{array}$ & Yellow \\
\hline \multicolumn{2}{|c|}{ SNI-06-0463-1989-A } & $\begin{array}{l}\text { Less } \\
\text { elastic }\end{array}$ & - \\
\hline
\end{tabular}

*Accordance with Munsel color chart

ning agents. The lower the chromium concentration the slighter the leather elasticity will be. It is one of the chromium strengths as tanning agent. According to Purnomo (1997); Brown et al. (2011); Roig et al. (2012); Nasr et al. (2013), the use of chromium in tanning process could produce more elastic leather, heat resistant, higher tensile strength, higher stability, strong, and smoother. The tanned leather product would be better if it was dyed by using indelible dye.

The leather color is examined by using Munsell Color Chart as comparison. The common color of tanned leather by using gambier concentration was yellow. According to Kardel et al. (2013), gambier condensed tannin extracted mainly from leaves and small branches, using plant-based agents was relatively stiff and produced colored tanned leather based on the tanning agents used. The color of tanned leather in the combined tanning agents of chromium and $8 \%$ gambier concentration could produce various color of leather, ranged from light brownish to light gray.

\section{CONCLUSION}

Minimizing the use of chromium in the combined tanning process of chromium and gambier can be implemented to the lowest of $2 \%$ chromium concentration and $8 \%$ gambier in the first and second step, respectively. Tanning leather product with the lowest chromium concentration and $8 \%$ concentration of gambier in the following step shows tanning level at $31.22 \%$, tensile strength at $386.30 \mathrm{~kg} / \mathrm{cm}^{2}$, elasticity $31.91 \%$, thickness $1.3 \mathrm{~mm}$, density $0.67 \mathrm{~g} / \mathrm{cm}^{3}$, the skin condition is fairly elastic and the color is light brownish. 


\section{ACKNOWLEDGEMENT}

The authors would like to thank Directorate General of Higher Education (DIKTI) for financing this research through MP3EI scheme with contract No. 118/SP2H/PL/Dit. Litabmas /III/2013. To the head of Balai Besar Penyamakan Kulit Karet dan Plastik (BBKKP) Yogyakarta for assisting in the leather sample examination.

\section{REFERENCES}

BPS Provinsi Sumatera Barat. 2008. Statistik Perdagangan Luar Negeri Sumatera Barat Ekspor-Impor 2008.

Badan Standarisasi Nasional. 1989. Standar Nasional Indonesia (SNI No, SNI 06-0994-1989-A). Cara uji derajat penyamakan kulit tersamak.

Badan Standarisasi Nasional. 1989. Standar Nasional Indonesia (SNI No, 06-0463-1989-A). Kulit Lapis Domba/Kambing Samak Kombinasi (Krom dan Nabati).

Badan Standarisasi Nasional. 1989. Standar Nasional Indonesia (SNI-06-0253-1989). Kulit Glace Kambing.

BASF. 2013. Pocket Book for the Leather Technologists. Fourth Edition. BASF Aktiengeseilschaft, 67056 Ludwigshafen. Germany. Diakses Februari 2013 melalui http://www.basf. com/Leather.

Balai Besar Penyamakan Kulit, Karet, dan Plastik. 2011. Metode Penyamakan Kulit. Balai Besar Penyamakan Kulit, Karet dan Plastik. Yogyakarta.

Brown, E. M. \& D. C. Shelly. 2011. Molecular modeling approach to vegetable tanning: preliminary results for gallotannin interactions with the collagen microfibril. JALCA 106:145-152.

Darmawan, R. A. B. 2012. Pengaruh penggunaan lumpur limbah industri penyamakan kulit terhadap penyerapan krom pada tanaman sawi (The effect of leather tanning industry waste utilization on cromium adsorption of green mustards). Majalah Kulit Karet dan Plastik. 28: 69-78.

Dhalimi, A. 2006. Permasalahan gambir (Uncaria gambir L.) di Sumatera Barat dan alternatif pemecahannya. Perspektif 5: 46-59.

Faber, K., A. G. Bayer, \& H. Spahrkas. 1978. Ullmanns Encyklopadie der technichen chemie. Tanning Material. Verlag Chemie GmbH. Weinheim. New York.
Ghani, A. 2011. Effect of chromium toxicity on growth, chlorophyll and some mineral nutrients of Brassica juncea. Egypt Academic Journal Biology Science 2: 9-15.

Haron, M. A., P. Khirstova, G. A. Gasmelseed, \& A. Covington. 2012. Potensial of vegetable tanning material and basic aluminium sulphate in Sudanese leather industy (Part II). Journal Science Technology 19: 32-41.

Ibrahim, L., I. Juliyarsi, \& S. Melya. 2005. Ilmu dan Teknologi Pengolahan Kulit. Fakultas Peternakan Universitas Andalas, Padang.

Jun, R., T. Ling, \& Z. Guanghua. 2009. Effects of chromium on seed germination, root elongation and coleoptiles growth in six pulses. International Journal Environment Science Technology 6: 571-578. http://dx.doi.org/10.1007/ BF03326097

Kardel, M., F. Taube, H. Schulz, W. Schutze, \& M. Gierus. 2013. Different approaches to evaluate tannin content and structure of selected plant extracts-review and new aspects. Journal of Applied Botany and Food Quality 86:154-166.

Kasim, A., D. Novia, S. Mutiar, \& J. Pinem. 2013. Characterization of goat skin on preparation of leather tanned with gambier and properties of leather. Majalah Kulit, Karet dan Plastik 29:55-62.

Nasr, A. I, M. M. Abdelsalam, \& A. H. Azzam. 2013. Effect of tanning methode and region on phisical and chemical properties of barki sheep leather. Egyptian Journal of Sheep and Goat Science 8:123-130.

Roig, M., V. Segarra, M. A. Martinez, J. Ferrer, \& C. Raspi. 2012. Chrome-free leather, tanned with oxazolidine. Journal of Aqeic 63: 101-109.

Sahubawa, L., A. Pertiwiningrum, \& A. T. Pamungkas. 2011. Pengaruh kombinasi bahan penyamak formalin dan syntan terhadap kualitas kulit ikan pari tersamak. Majalah Kulit, Karet dan Plastik. 27: 38-45.

Suparno, O., A. D., Covinton, \& C. S. Evans. 2010. Teknologi baru penyamakan kulit ramah lingkungan: penyamakan kombinasi menggunakan penyamak nabati, nafto dan oksazolidin. Jurnal Teknologi Industri Pertanian 18: 79-84.

Wina, E., I. E. R. Susana, \& B. Tangendjaja. 2010. Biological activity of tannins from acacia mangium bark extracted by different solvents. Med. Pet. 33:103-107. http://dx.doi. org/10.5398/medpet.2010.33.2.103.

Wiyodiningrat, S., R. Setyamurti, \& I. F. Pahlawan. 2012. Pembuatan kulit jok (upholstery) ramah lingkungan untuk otomotif (Research on making environmentally friendly upholstery leather/carseat for automotive). Balai Besar Kulit, Karet dan Plastik 28: 09-17. 